\title{
Brazil: Chartering a New Economic Pathway
}

\author{
Raul Gouvea ${ }^{1}$ \\ ${ }^{1}$ Anderson School of Management, University of New Mexico, United States \\ Correspondence: Raul Gouvea, Anderson School of Management, University of New Mexico, United States.
}

Received: October 31, 2019

doi:10.5539/ibr.v13n1p145
Accepted: December 9, 2019 Online Published: December 13, 2019

URL: https://doi.org/10.5539/ibr.v13n1p145

\begin{abstract}
The presidential elections of 2018 marked an inflection point in Brazil's quest towards establishing a sustainable economic pathway. The "populist years" of Brazil's hard left, has resulted in economic stagnations, losses of economic competitiveness, massive corruption, and high levels of unemployment. In 2019, Brazil's new administration is introducing a private sector-led economic growth strategy, instead of the state-led growth strategy of previous decades. This paper will elaborate on the new economic paradigm being set in place and its likely impact on Brazil's economy and business environment.
\end{abstract}

Keywords: Brazil, Bolsonaro, market-oriented reforms

\section{Introduction}

In 2019, Brazil's economy is undergoing a drastic departure from the last three decades. The Bolsonaro administration is implementing a number of business-friendly measures to improve Brazil's economy and business environment. These changes constitute an inflection point in Brazil's quest to increase its economic competitiveness and promote an inclusive sustainable economic development and growth agenda. Brazil's GDP growth has been well below its potential for the last few years. On the bright side, Brazil in 2019 has one of Latin America's most dynamic trade sectors, healthy international reserves, and low rates of inflation. On the other hand, Brazil has a high unemployment rate, a growing domestic debt as a percentage of GDP, numerous environmental challenges, and a number of pressing social, political, and economic challenges. In addition, Brazil is still addressing the impacts of many years of high corruption levels that affects Brazil's political, social, and economic environments (Martins and Furlan, 2019; Cohen, Stefano, and Jankavski, 2019; Ming, 2019; Santos, 2019; Von Doellinger, 2019).

In 2019, Brazil's economy is also affected by lower levels of global economic growth, and lower levels of global trade. The World Trade Organization (WTO) expects that global trade will only expand by $2.6 \%$ in 2019, down from $3.0 \%$ in 2018 . Global economic growth is also expected to only expand by $3.2 \%$, and emerging economies are expected to only expand by $4.1 \%$, the lowest in about a decade. This uncertain global economic scenario imposes additional burdens on Brazil's economic recovery. A weaker global economic growth has the potential to reduce Brazil's GDP by $0.2 \%$ in 2019 , and maybe up to $0.5 \%$ in 2020. (Carranca, 2019; IMF, 2019; OECD/ECLAC, 2019; WTO, 2019).

\section{Brazil's Economy: Main Indicators}

In 2019, Brazil's economy was ranked $9^{\text {th }}$ in the world, with a nominal GDP of US\$2.09 trillion. In 2010, Brazil's economy was ranked $7^{\text {th }}$ in the world, with a nominal GDP of US\$ 2.08 trillion. Brazil's economic performance has been quite disappointing in comparison to other emerging countries. For instance, India a BRIC country, was able to achieve much higher rates of economic growth during the same period. For instance, India saw its nominal GDP increased from US\$ 1.7 trillion in 2010 , to close to US\$ 2.9 trillion in 2019 , ranking $6^{\text {th }}$ in the world. Brazil's state-led growth strategy has not resulted in higher rates of economic growth, contrary to India's more business friendly business environment (World Bank, 2019a,c).

Brazil has also lost substantial ground on its overall economic competitiveness. In 2010, Brazil was ranked by the World Economic Forum's Global Competitiveness Index, $56^{\text {th }}$ in the world. In 2018, Brazil was downgraded to the $72^{\text {nd }}$ position. As a result of a continuous decline in competitiveness, Brazil has also lost substantial ground on the GDP per capita dimension. For instance, in 1980, Brazil's GDP per capita was 39\% of the U.S. GDP per capita. In 2018, Brazil's GDP per capita was only $25.8 \%$ of the U.S.' GDP per capita (Lamucci, 2019; World Bank, 2019a). 
The past administrations have also neglected important economic, business, and political reforms leading to the creation of a very complex and not very friendly business environment. For instance, in 2018, the Heritage Foundation's Economic Freedom Index, ranked Brazil's economy in $140^{\text {th }}$ place, labelling Brazil's economy as "mostly unfree." The stagnation of Brazil's business environment can be seen from the World Bank's Doing Business Reports. The 2010 Doing Business Report, ranked Brazil's business environment $129^{\text {Th }}$ out of 183 countries. The 2019/2020 Doing Business Report ranked Brazil in $124^{\text {Th }}$ place. Thus, in the last ten years, Brazil's business environment has not shown any perceived improvement, aggravating the country's competitiveness and economic growth and development perspectives (Heritage Foundation, 2019; World Bank, 2019b).

Brazil's Logistic Performance Index rankings also shed additional light in one of Brazil's Achilles' heel: infrastructure and logistics. The World Bank's Logistics Performance Index (LPI) sheds light on Brazil's poorly developed logistics and infrastructure. Brazil's "soft" and "hard" logistics needs urgent improvement. The 2018, LPI ranks Brazil in $56^{\text {th }}$ place, what creates a number of barriers for Brazilian exporters and importers in addition to compromise Brazil's ability to place their products competitively in global markets (World Bank, 2018).

In a globalized knowledge - driven economy, Brazil's lack of attention to R\&D and Innovation has also paralyzed and affected Brazil's economy overall competitiveness. For instance, WIPO's 2019 Innovation Index ranks Brazil as $66^{\text {th }}$, well below other Latin American countries such as Mexico, and again incompatible with a country that aims to grow and develop in the next decades. On average, Brazil has invested close to $1.1 \%$ of its GDP on R\&D, a percentage well below other emerging economies. The internet of Things revolution and Manufacturing 4.0 are bound to create a new technological inflection point, further affecting economies' competitiveness with low levels of investment and attention to R\&D and innovation, like Brazil's. Brazil is running the risk of getting caught in the innovation and digital divide with severe implications for the country's economic development and growth.

Brazil's educational system has also been the object of many criticisms. Even in Latin America, countries like Chile have achieved higher rates of success in their educational systems than Brazil has. According to the latest OECD 2015's Programme for International Students Assessment - PISA, Brazil was ranked in $64^{\text {th }}$ place out of 71 countries. A dismal result for a country amongst the top ten economies in the world. Education is a crucial pillar for an economy to retain and gain competitiveness and a pre-condition for the implementation of a sustainable, inclusive, and equitable economic development and growth strategy (OECD, 2015; WIPO, 2019).

Despite decades of a state-led economic development strategy, Brazil is still a country with acute social and income disparities. For example, Brazil's Gini coefficient index, measuring relative wealth distribution, indicates that Brazil still has a very unequal distribution of income, around 51.30, well above other Latin American countries such as Mexico with 43.4, and Argentina close to 40.6. This is a surprising outcome, giving the claims of past leftist governments in Brazil that they had addressed one of Brazil's main economic and social issue bottleneck: income distribution (World Bank, 2019c).

Brazil's performance in the latest United Nations Human Development Index (HDI) that measures health, access to education, and standards of living, also shows that Brazil still has a long road ahead. The 2017 HDI ranks Brazil $79^{\text {th }}$, out of 189 countries, showcasing Brazil's skewed distribution of income, low quality educational systems, and low quality of its health services. The lack of investments on health care can be viewed by Brazil's increasing epidemics. For instance, during the first half of 2019, Brazil had 600,000 dengue cases. In the same period of 2018, Brazil had 173,000 cases of dengue. Zika and Chikungunha are also making significant inroads in Brazil's territory. But other disease such as measles are also staging a comeback. These epidemics are a direct result of past governments lack of attention to the health sector and also a result of corruption schemes that took resources away from Brazil's health sector. Brazilian levels of vaccination are also well below international levels. The Bolsonaro administration has a number of challenges ahead of them. Addressing a number of potential Bio Risks scenarios will be important in preventing or alleviating future epidemics and pandemics (UN, 2019; Mendonca, 2019).

Information and Communication Technologies are becoming important tools in the design of more competitive economic and business environments. From agriculture to manufacturing and services, ICTs permeates a number of social, economic, and environmental dimensions of economies and societies around the globe. Brazil is also lagging behind other nations in this dimension. According to the 2017 ITU's ICT Development Index, Brazil ranked $66^{\text {th }}$. In order to have a more competitive and efficient economy and business environment, Brazil will have to increase the penetration and expansion of ICT technologies and services. Brazil's initiatives in the Internet of Things and Manufacturing 4.0 are highly dependent on Brazil's ability to establish a pervasive and 
efficient ICT network. Brazilian companies are still not utilizing AI, big data cloud computing, and 3D technology as extensively as one finds in other countries, with deep implications for Brazilian companies' productivity and competitiveness. When it comes to internet access, however, only 126 million Brazilians had access to the internet in 2016. In 2017, only 53\% of the Brazilians at the bottom of "Brazil's Pyramid" had access to the internet. Compared to $97 \%$ of Brazilian in the top of Brazil's Pyramid. (Deloitte, 2019; Lavado, 2018; ITU, 2019).

Brazil's environmental policies and guidelines are also being questioned and scrutinized. The country still lacks adequate access to sewage and water treatments. Recently, Brazil's Amazon region is also receiving a lot of attention, as a result of fires and deforestation. According to Yale's 2018 Environment Performance Index, Brazil was ranked $69^{\text {th }}$, out of 180 countries. These results also show that Brazil could be doing a much better job in addressing its environmental issues and bottlenecks (Gouvea and Montoya, 2014; Yale University, 2018).

Brazil has never been a corruption free country, however, in the past decades Brazil's economy and society has been deeply affected by increasing levels of corruption. These corruption schemes have used resources destined to Brazil's social, environmental, and economic programs, to be used for political and personal gains. For instance, in 2002 Brazil was ranked by Transparency International's Corruption Perception index in $45^{\text {th }}$ place. In 2018, Brazil had slipped to $105^{\text {th }}$ place. Recent measures and policies, such as the "Lava Jato" operation, have resulted in a number of politicians, bureaucrats, and some of Brazil's leading business leaders being jailed on charges of corruption. In 2019, Brazil had two former presidents in jail. This outcome was unthinkable few years ago. Brazil is taking the first steps to support and strengthen its institutions a sine qua non condition for Brazil to establish effective governance and to achieve higher levels of economic development and growth (Stephenson, 2019; Transparency International, 2019; Valenti, 2019).

In sum, Brazil's past administrations have deeply compromised Brazil's overall economic, social, and environmental competitiveness. In 2019, Brazil faces a number of barriers and bottlenecks to unleash its economic potential. The next section will discuss measures being taken by the Brazil's new administration to address a number of these barriers and bottlenecks.

\section{Addressing Brazil's Pillars of Sustainable Economic Growth and Development}

After years of neglect, the Bolsonaro administration is tackling a number of pressing reforms and changes needed in Brazil's economy and business environment. High levels of red tape, fiscal imbalances, high levels of unemployment, declining productivity and competitiveness, and a highly protected economy, are fostering these changes and measures (Gouvea, 2014; Holland, 2019; Gendreau and McLendon, 2019).

In 2019, Brazil's economy is still recovering from its worst recession in more than five decades. Between 2014-2016, Brazil's GDP contracted by 7\%, and the economy is still feeling the effects of this aggressive recession. For instance, in the period between 2014 and 2019, manufacturing production has contracted by $16.7 \%$, retail by $5.8 \%$, services by $11.75 \%$, and construction by $26.5 \%$. In $2019,12.5$ million Brazilians were unemployed, a 11.8\% rate. Brazil's 2014-2016 economic recession is taking much longer to end than initially anticipated (Eichengreen, 2019; Goncalves, 2018; Gouvea, Kapelianis, and Montoya, 2018).

Brazil's recession of 2015-2016, has led to one of the lowest rates of investment by the Brazilian government, from $1.48 \%$ of Brazil's GDP in 2014, to only $0.52 \%$ in 2018 . Investments on infrastructure, purchases of capital goods and equipment, in addition to expenditures to keep the federal government running have been cut substantially, deeply affecting overall economic activity. During the same period of time, Brazil lost 2.86 million jobs. Moreover, the recession of 2014-2016 had a great impact on the number of Brazilians living in extreme poverty. Their number increased from $3.2 \%$ in 2014 to $4.8 \%$ in 2017. According to the consulting company Kantar WorldPanel, close to $40 \%$ of household income in Brazil is made of income transfer programs and/or related to Brazil's informal economy. In 2019, Brazil had close to 44 million Brazilians living with less than US\$ 5.5 dollars a day. Between 2014-2017, more 7.4 million people joined this group, further aggravating Brazil's social woes (Chiara, 2019; Villas Boas, 2018; Pupo, 2019).

For the last three decades, Brazilian policymakers have been postponing addressing Brazil's pension reform. In 2019, the pension reform was a sine-qua-non condition for Brazil's ability to achieve higher levels of fiscal stability. Brazil spends close to $12 \%$ of its GDP on pensions, a very high percentage when compared to OECD countries. The Bolsonaro's administration made the pension reform one of its most immediate goals. In the Fall of 2019, Bolsonaro's Pension reform proposal was approved by Brazil's Senate and Lower House. The Pension Reform will add more fiscal stability and will potentially save US\$300 billion in the next ten years. As a result of the pension reform, additional resources will be available for investments in education, infrastructure, and health care, among other social and economic goals and objectives. The new guidelines will raise retirement 
age for men and women, 65 and 62 years respectively (Di Cunto, Lima, and Ribeiro, 2019; Secretaria de Politica Economica, 2019; Gendreau and McLendon, 2019; Gutierrez, 2019).

The Bolsonaro Administration has devised four major programs to unleash Brazil's entrepreneurs and investors "animal spirit": a) "Simplifica", b) "Emprega Mais", c) "Brasil 4.0", and d) "Pro Mercados." The "Simplifica" aims at streamlining 50 measures to lower the level of Brazil's bureaucracy that affects Brazilian companies. For instance, the government is reformulating the "eSocial" a number of complex labor procedures that companies must report to the government. The "Emprega Mais" program will allocate resources and efforts to develop retraining labor programs that will increase the skills and effectiveness of Brazilian workers. In the "Pro-Mercado" program, a number of government monopolies will be phased out, allowing private companies to participate in industries such as oil \& gas, increasing the competition in these industries. The "Brasil 4.0" will foster and estimulate the use of of new technologies in Brazil's business environment. BNDES will extend financing for companies that invest in new technologies.The "Economic Freedom Provisory Measure" was approved by Brazil's Lower House and Congress, addressing the burden on Brazil's private sector. The elimination of red tape and bureaucracy have the potential to create 3.7 million new jobs and expand Brazil's GDP by 7\% in the next few years (Rodrigues, 2019a; World Bank, 2019b).

The Bolsonaro administration has placed a special emphasis on redesigning the role of the state in Brazil's economy. Past administrations have created new state-owned enterprises (SOEs) that have become detrimental to Brazil's economy. Several of these SOEs have been the object of corruption, mismanagement, and political use. The Bolsonaro administration wants to reduce the number of SOEs operating in Brazil's economy, increasing the level of transparency, competitiveness, and efficiency of Brazil's business environment (Vargas, 2019).

Bolsonaro's government is set on privatizing a number of state-run companies. The expectation is that the privatization program in course will raise between US\$ 162-118 billion. The Bolsonaro administration has pledged to only keep 12 SOEs, or a privatization of 122 federal SOEs in the next four years. Directly and indirectly the Brazilian government has shares in 637 firms. Eletrobras is one of these SOEs that will hit the block in the next few months. Brazil is not currently including Petrobras, Banco do Brasil, Caixa Economica Federal and BNDES in the privatization program (Fucs, 2019, Endo, 2019; Estado de Sao Paulo, 2019a).

The Bolsonaro administration is also bringing a number of federal services to the $21^{\text {st }}$ century by digitizing them. The expectation is that there will be savings on average of $90 \%$ of the costs of these services for the state, with savings expected to reach US\$ 2 billion. The new program SEME (State Modernization Agency) is delivering 400 services online and expecting to deliver another 600 services on line by next year. A number of them will improve Brazil's business environment. The Bolsonaro administration is transforming Brazil into a digital nation, making public services more accessible and less costly. Brazil's addiction for red tape and paper copies of documents is finally coming to an end (Araujo and Ribeiro, 2019; World Bank, 2019b).

Brazil needs to urgently promote a political reform. Over the years, Brazil saw the proliferation of political parties. Currently, Brazil has one the largest number of political parties in the world. Brazil has 30 political parties, it is an extremely fragmented political environment, what makes any negotiation with Brazil's lower house and Brazil's Congress an extenuating task. President Bolsonaro will have to have very acute skills to deal with this extreme fragmentation and representation of a diverse political spectrum. In the past, governing by coalition has led to Brazil's largest corruption scheme ever. Brazil needs a political reform where among its goals, would be the goal to reduce the number of political parties. In the 2018 elections, the lower house had a 52\% renovation, the highest rate of new politicians for the past 20 years, and the number of female representatives increased to 77, out of 513 representatives. There is hope that new members will be more willing to gather around Brazil wide goals and objectives, rather than political parties' specific agendas and personal interests (Amorim, 2018; Collor, 2015; Di Cunto, 2019; Calheiros, 2019).

After approving the pension fund reform, Brazil needs to address its tax reform. There are several proposals being considered. One of them contemplates the unification of taxes on goods and services (ICMS, IPI, PIS, e Cofins) in a true IVA format, that do not tax exports. It is a proposal that mirrors the tax system found in many European nations. In 2018, taxes accounted for 35.07\% of Brazil's GDP deeply affecting Brazil's competitiveness and overall prices, including exports. In addition, it also inhibits innovation since a number of companies don't have the means to afford investing on innovation after paying high taxes. High taxes also induce companies to become players and members of Brazil's underground economy (Pastore, 2019; Pereira, 2019a).

Over the past decades, Brazil's private sector has pledged for lower levels of taxation. Brazil' has one of the world's highest taxes as well number of tributes. Brazil has close to 66 tributes at the federal, state, and 
municipal levels. Brazil's main tributes are ICMS and IPI. Brazil's overall tax system tend to overburden consumption more than income and patrimony. It is also important to equalize tax burdens across industries in Brazil. For instance, the service industry is less taxed than Brazil's manufacturing sector. The Bolsonaro administration is trying to streamline Brazil's tax system as well as reducing the number of tributes in a more comprehensive and effective fashion (Fraga, 2019a).

Brazil's National Bank of Economic and Social Development (BNDES) is going back to its historical goals and objectives. For the last decades, BNDES has been used to favor a handful of "national champions" many of them deeply involved in Brazil's largest corruption scandal - "the Lava Jato Operation." In 2019, BNDEs is increasing its financing to Brazilian SMEs. In 2013, only close to $20 \%$ of BNDEs financing were allocated to Brazilian SMES. In 2019, the goal is to increase financing to SMES to close to 49\% of the BNDES's total financing. Over the past decades, BNDES could have promoted the creation of an affluent and dynamic SME business environment, leading to further gains for Brazil's economic democracy and jumping starting a strong middle class. (BNDES, 2019; Otta, 2019a).

The state-led economic development agenda also resulted in a very large contingent of federal, state, and municipal workers. In 2019, Brazilian expenditures with government workers at the federal, state, and municipal levels reached 13.6\% of Brazil's GDP, well above other Latin American countries such as Mexico (5.3\%), and Chile (6.6\%). In millions of workers, the federal level hires 1.19 million, state level hires 3.75 million, and municipal level hires close to 6.5 million workers. Despite Brazil's negative GDP contraction of $4.2 \%$, and a manufacturing contraction of $14.2 \%$, the share of expenditures with staff increased from $12.3 \%$ share in 2014 . Moreover, despite Brazil's substantial number of government workers, Brazil's government effectiveness is ranked very low. According to the Government Effectiveness Index, assembled by The GlobalEconomy.com, Brazil's ranked $111^{\text {th }}$, compared to Chile's $42^{\text {nd }}$, Argentina's $74^{\text {th }}$, and Mexico's $89^{\text {th }}$ ranking. Thus, the low quality of Brazil's government workers increases the burden on the government's budget and does not advance Brazil's overall economic competitiveness agenda (Cafardo, 2019; Patu, 2019).

The Bolsonaro administration is also developing a program to increase Brazil's productivity and competitiveness. Brazil's labor productivity only increased by $1.3 \%$ between 1990 and 2018, compared to $8.8 \%$ for China and $5.0 \%$ for India. The low penetration of technology in Brazil's business environment, low levels of education, poor infrastructure, and low exposure to global competition, among other factors, does not provide an incentive for Brazilian companies to innovate. Brazil's tax system also does not provide incentives for innovation. Brazil needs urgently to increase its productivity rates in order to achieve higher rates of economic development and growth (Goitia, 2019; Menezes Filho, Campo, and Komatsu, 2014; Matsumura, et al., 2019).

\section{Inflection Points}

\section{Energy Production}

The Bolsonaro administration wants to lower the cost of doing business in Brazil by lowering the cost of energy. Brazil has a substantial potential when comes to renewable sources of energy as well as a sizeable reserve of fossil fuels. The Bolsonaro administration is setting in place incentives for the expansion of supply of renewable and non-renewable sources of energy, such as the elimination of state monopolies and barriers for the participation of the private sector in these industries. The expansion of the share of renewable sources of energy, such as solar and wind, is a key departure from past administrations.

Brazil has one of the cleanest electricity matrixes in the world. In 2018, the share of renewables reached $83 \%$, up from 78\% in 2013. Around the globe most of the electricity generated relies on coal, petroleum, and nuclear power. In Brazil, hydropower accounts for $63.8 \%$, wind for $9.1 \%$. Thermoelectric power plants relying on coal and petroleum, are now only accounting for $15.5 \%$ of all the electricity generated in Brazil, down from $19.8 \%$ in 2013. In 2019, the share of solar energy is also expanding. Brazil is also the world's second largest market for biofuels, such as biodiesel (Ministerio de Minas e Energia, 2019; Morais, 2019).

In 2019, Brazil had 15.8 GW of wind energy installed, with 4 more GW expected by 2023. In 2011, Brazil had only $1.5 \mathrm{GW}$ of wind energy installed. Most of Brazil's wind energy units are located in the Northeast region, close to $86 \%$ of all installed power plants in Brazil. Companies like the Danish company Vesta have been investing heavily in Brazil's wind energy industry. Gradually, companies are moving to explore wind energy offshore. The Norwegian company Equinor is going to install in the Northeast region the first units by 2022 (Ministerio de Minas e Energia, 2019; Adeodato, 2019).

Brazil has recently also stressed the use of solar energy. Brazil's geographic location presents a good opportunity for the expansion of solar power in the country. Currently, Brazil produces close to $3.1 \mathrm{GW}$ of solar energy, 
expected to reach $13.6 \mathrm{GW}$ by 2030 . Contrary to wind energy, solar energy is mostly produced in the Southern region of Brazil, with states like Minas Gerais, Rio Grande do Sul, and Sao Paulo accounting for most of the investments and production. Most of the solar energy is directed towards consumers. Residential consumers account for close to $74 \%$, services and retail account for $17 \%$ of total consumption. A number of companies are moving into the solar energy industry in Brazil. For instance, Lightsource BP is increasing its exposure to the Brazilian solar markets acquiring 2GW gigawatts in projects (Ministerio de Minas e Energia, 2019; Maia, 2019).

One of the Bolsonaro's administration new energy program is aiming at reducing the price of natural gas for industrial use. "The Natural Gas Market" program aims to reduce the price of natural gas by $40 \%$. Currenty, Brazilians are paying around US\$ 12-14 for 1 million BTU, the proposal is to reduce the price of 1 million BTU to around US\$ 7-8 per 1 million BTU. That will lower the cost of manufacturing in Brazil. Brazil's chemical sector, ceramics, steel, food and beverages, paper \& pulp are Brazil's main consumers of natural gas to supply their energy needs. In 2019, Brazil discovered new natural gas fields with a potential daily production of 20 MMcmd of natural gas, accounting for close to one - third of Brazil's current production. This discovery will help in generating a "cheap energy shock" in Brazil that will lower the cost for industries relying on natural gas for their energy needs. The government also wants to encourage more investments in the sector, disrupt monopolies, and diversify and expand the number of companies that are currently operating in the segment. Manufacturing accounts for close to $52 \%$ of all-natural gas consumption, followed by the electricity generation industry with $33 \%$ of all consumption. Petrobras accounts for $77 \%$ of Brazil's natural gas production and for $100 \%$ of the infrastructure and logistics. The Bolsonaro government wants to break Petrobras' monopoly and allow more competition in the industry at the distribution and transportation levels as well (Ministry of Economy, 2019; Warth and Lindner, 2019).

The Bolsonaro administration is also opening up the oil onshore production to the private sector. Petrobras has emphasized offshore oil production resulting in a drastic reduction in the onshore production from 210,000 barrels daily in 2002 to close to 107,000 barrels daily in 2019. Brazil has only 23,000 onshore oil wells perforated compared to 2 million in the US. Petrobras will sell 183 exploration concessions in 2019 and beyond. It is expected that by 2030 onshore production will reach 500,000 barrels daily. Close to $90 \%$ of Brazil's oil reserves lie offshore, most of them in deep water. The Bolsonaro administration is also favoring the privatization of offshore oil fields. The first ones to be privatized are located off the coast of the state of Bahia, in the Northeast region of Brazil. Brazil has the second largest oil reserves in Latin America, after Venezuela (Ministerio de Minas e Energia, 2019; Favaro, 2019).

\section{Foreign Trade Policy}

In 2019, Brazil has finally ended its lethargic foreign trade policy. In 2018, the share of exports and imports of goods and services in Brazil's GDP was 24.6\%, lower than Colombia's at 35\%, and South Korea at $78 \%$. Brazil's protectionist measures have deeply penalized Brazil's economy and have resulted in lower levels of competitiveness and productivity when compared to countries that show a higher share of export and imports in their respective GDPs (Romero, 2019; Troyo, 2019).

The Bolsonaro administration is rapidly designing a number of bilateral trade agreements in the Americas, Europe, and in Asia. In 2019, the Bolsonaro administration is also pushing for Brazil and Mercosur to expand its portfolio of trading partners. The 2019 EU-Mercosur trade agreement has been in the works for at least two decades. In 2019, Brazil and the other members of Mercosur finally concluded the trade agreement with the European Union. The European Union is one of Mercosur's main trading partners. The EU-Mercosur trade agreement will allow Brazil to increase its exports to EU markets, and at the same time brings Brazil back into the global trade game (Grieger, 2019).

Brazil and the U.S. are also designing a bilateral trade agreement. It is an overdue development. Both countries have developed a solid trade and investment partnership over the past decades. The proximity between President Trump and President Bolsonaro is fostering the trade and investment ties between the two countries. This development constitutes an inflection point in Brazil and U.S. relationship. Since 1994, Brazil has kept distance from the U.S and has not agree to engage in bilateral free trade agreement discussions. The Bolsonaro administration has interrupted this anti-American posture by previous Brazilian administrations. In 2018, Brazil exported US\$28.7 billion worth of goods, while Brazil imported US\$29 billion from the U.S. The U.S. economy offers a good complementarity and integration for the Brazilian economy. Clearly, there is room for growth in the U.S. Brazil relationship. The agreement would involve trade facilitation, reduction of non-tariff barriers, intellectual property policies and guidelines, e-commerce, among other items (Leal and Gouvea, 2018; Rodrigues and Agostini, 2019; Dalpiva and Setti, 2019; Barbosa, 2019) 
The U.S. and EU compete in the Brazilian market for US\$ 59 billion worth of Brazilian imports. Their direct competition covers 906 products, that range from fuels, pharmaceutical products, chemicals, fertilizers, medical equipment, steel, and plastics among other products. These are manufactured products of medium to high valued added. That is one of the reasons why both the EU and the U.S. are so interested in reaching free trade agreements with Brazil at this point (Rittner, 2019). Brazil also signed an agreement with the U.S. to facilitate the penetration of U.S. engineering companies in Brazil. Brazil will be able to tap on a US\$ 60 billion fund to finance infrastructure projects in emerging countries (Otta, 2019b).

The Bolsonaro administration is also developing a closer trade partnership with Japan. Japan is Brazil's sixth largest investor. Brazil used to be Japan's main destination for trade and investment in Latin America. Currently, Mexico is Japan's main focus of attention for its FDI in the region. Japan is Brazil's eight largest market for its exports. Brazilian exports to Japan have reached US\$ 10 billion in the past, currently is around US\$ 2 billion for the first six months of 2019. Imports from Japan are also around US\$ 2 billion for the first six months of 2019. In 2017 Japan exported close to US\$ 5 billion to Brazil and imported US\$ 3.7 billion from Brazil, with FDI in 2016 valued at US\$ 1.1 billion (Jetro, 2018; Banco Central do Brasil, 2019).

In 2019, Brazil has also signed a free trade agreement with Mexico. Both countries have much to offer to one another. Brazil will also deepen its trade ties to other Latin American economies in order to increase the competitiveness and efficiency of Brazil's economy. Brazil has not been a player in the global value chains so far. The current administration wants to insert Brazil back in the global economy (Mano, 2019).

The Bolsonaro administration has also been working closely with other members of Mercosur to modernize the common market, trying to eliminate a number of existing barriers that prevent more intra-Mercosur trade. Mercosur is an important destination for Brazilian exports and imports. For instance, Brazil is Argentina's largest trading partner accounting for close to $21 \%$ of Argentina's total imports. In 2018, the total flow of trade between Argentina and Brazil reached US\$ 26 billion. Argentina is Brazil's third largest trading partner (MDIC, 2019).

The Bolsonaro administration is also developing a close relationship with China. In 2018, China was responsible for $26.8 \%$ of Brazil's total exports. In 2018 Brazil exported US\$ 64.2 billion to China, mostly commodities. China has had a very important impact on Brazil's economy at the trade and foreign direct investment levels. Between 2014-2017, Brazil was China's second destination in the world for FDI, just after the U.S. In 2017, Chinese FDI in Brazil reached US\$ 11.7 billion. Chinese FDI has targeted Brazil's service industry, manufacturing, and primary industries. The Bulk of Chinese investments, $79 \%$ have been in Brazil's electricity sector and in the Oil \& Gas industries. Mining accounts for 8\%, automotive 4\%, Agriculture 4\%, and financial services 3\%. Since 2009, Chinese companies have invested close to US\$ 53, billion, in 29 Greenfield projects and in 72 Brownfield operations. Brazil has benefited from the China-U.S. trade conflict. Brazil has gained additional shares of China's market, for instance soya bean exports are 35\% higher in 2019. On average, Brazilian exports to China have expanded by US\$ 8.1 billion as a result of the U.S.-China trade dispute (Agostini, 2019; Gouvea, Kapelianis, and Lee, 2019; Otta, Nunes, and Barista, 2019; Watanabe, 2019).

\section{Agribusiness}

In less than 50 years, Brazil has moved from being a food importer to being the world's second largest food producer, and a major exporter of proteins. In the last 40 years, Brazil became a top 5 exporter of 36 agricultural commodities. In 2019, the agribusiness industry accounts for a large share of Brazil's exports and for close to $21.6 \%$ of Brazil's GDP. In 2019, Brazil accounted for close to 95\% of global exports of frozen orange juice, 50\% of the soya bean complex, $35 \%$ of global poultry exports, $34 \%$ of global sugar exports, $30 \%$ of all coffee trade, and for close to $17 \%$ of global beef trade. But the country only accounts for close to $1 \%$ of all global trade of fruits. (Luque, Silber, Zagha, 2019; Ministerio da Agricultura, 2019; Rodrigues, 2019b).

Brazil is the only country in the world with a potential to expand its agricultural frontier by 15 million ha, a $21 \%$ growth in the next ten years. However, it must expand its agricultural production and frontier without harming the environment. In 2019, Brazil is being pressured to engage in more sustainable ways to develop and expand agribusiness in the Amazon region (Ministerio da Agricultura, 2019).

In 2019, Brazil is more than ever implementing efforts to preserve its ecosystems and increase its agricultural output. Brazil's past performance in biotechnology applied to its agribusiness industry has allowed the country to increase its agricultural output and still preserve its environment (Guimaraes, 2019). Brazil needs urgently to address illegal deforestation in order to further protect its environment. Currently, deforestation is a direct result of illegal activities taking place in regions of Brazil such as the Amazon region. Deployment of surveillance technology in much will improve Brazil's ability to identify and punish illegal deforestation. Rampant corruption in the past administrations has weaken Brazilian enforcement agencies and allowed deforestation to foster. 
Moreover, if Brazil does not strengthen its environmental efforts it will potentially face agricultural export losses as a result of environmental pressure from traditional trading partners such as the EU. Sustainability efforts, policies, and guidelines have been governing Brazil's agribusiness industry and will become even more important from now on (Lindner et al, 2019; Ortega, 2019; Guimaraes, 2019; Borges, 2019).

Brazil' agribusiness will also have to add more technologies and innovations in the next few years. Sensors, drones, robots, and automation will dominate Brazil's vast agribusiness industry. These technologies will increase Brazil's agribusiness efficiency, competitiveness, and sustainability. GMOs and CRISPR will also be utilized in the next two decades. More than ever, Brazil needs to increase its commitment to innovation and R\&D (Mondin, 2019).

\section{Sustainability}

Brazil is in its quest to balance economic development with environmental sustainability. The country has a number of visible gaps in this quest. Brazil's transition from a carbon-intensive economy to a green-driven economy demands a change in Brazil's institutions, mindset, and infrastructure. Brazil's Amazon region represents in a number of ways, Brazil's challenges and opportunities on the environmental front. Brazil's environmental challenges, however, go well beyond the Amazon region, from its logistics to solid residues disposal (Gouvea and Montoya, 2014).

In 2019, Brazil received a US\$ 500 million loan from BRIC's Development Bank to address its solid residues waste. Brazil has close to 3,000 landfills, without any treatment.. These open landfills should have been closed in 2014, according to Brazil's Abreipe (Brazilian Association of Waste Disposal and Solid Residues) and Brazil's agency in charge of designing policies and guidelines for solid residues. Brazil has produced an additional 28\% of waste between 2010-2017. However, the rate of recycling has only increased from 2\% in 2010 to about 3\% in 2017 (Borges, 2019b; Hartung, 2019).

Brazil only spends US\$ 2.5 billion yearly on sewage treatment, half of what Brazil currently needs. Brazil's Congress needs to approve Provisory Measure 868 that pushes for the standardization for municipalities and states to treat sewage. Brazil's Water National Agency (ANA) is waiting for Congress to move and approve the resolution. Close to 1,500 municipalities have no oversight over their sewage resources allocated from the federal government. This is another dimension of a lack of oversight of federal resources destined to Brazilian municipalities, that the Bolsonaro administration is trying to address. In some cities of Brazil, mostly in the Amazon region and Mid-West there is no charge to citizens for water \& sewage, making the attraction of private companies difficult. Moreover, in some other cities, the average charge does not comply with the cost of providing these services. So, PPS will be only feasible if these fees are readjusted. It is also worth mentioning that 72 million Brazilian do not have access to sewage treatment, the population of a country the size of France. Access to tap water is also another issue affecting millions of Brazilians, close to 19 million people do not have access to tap water (88.3\%), and 21 million Brazilians do not have access to garbage collection services or $9.7 \%$ of Brazil's population (Borges, 2019b; Filho, 2019).

The recession that started in 2015, coupled to lower levels of investments on basic services, has drastically affect Brazil's ability to comply with its MDGs. For instance, during the recession years, 2014-2016, consumption of wood and coal for cooking also increased by $27 \%$, reaching 14 million households. The increase in wood and coal consumption is a direct consequence of Brazil's increased unemployment, and lower costs of wood vis-à-vis electricity or natural gas (Villas Boas and Saraiva, 2019).

In 2019, the world is looking at Brazil's Amazon region. The Bolsonaro administration is devising a new governance for the region. More than 25 million Brazilians live in the region. Designing creative and pragmatic approaches to the sustainable development of the region is of paramount importance for Brazil. A balance must be achieved between sustainability and economic development in the region. The Ministry of Environment is working on a new blueprint for the region, addressing Brazil's main environmental, social, and economic goals for the region. An economic, social, and environmental zoning must be devised in order to promote the sustainable development of the region. Moreover, indigenous populations also need to be involved in this zoning process, creating an inclusive and equitable environment in the Amazon region (Gouvea, 1998; Vieira, 2018; Chiaretti and Vasconcelos, 2019; Vieira, 2019).

\section{Infrastructure}

The Bolsonaro's administration is heavily emphasizing investments on Brazil's infrastructure. Past administrations have neglected Brazil's infrastructure deeply affecting Brazil's overall economic competitiveness, efficiency, social inclusiveness, and equity. Brazil is lagging behind on a number of dimensions of 
infrastructure from railroads to telecommunications. The 2015-2016 recession forced the government to stop 4,000 projects, $20 \%$ of them being infrastructure related. In 2018 close to $1.6 \%$ of Brazil's GDP was invested on infrastructure, $2 / 3$ undertaken by the private sector and $1 / 3$ by the state. However, Brazil needs to invest at least $4.3 \%$ of its GDP in order for Brazil to restore and upkeep the existing infrastructure and upgrade and expand its infrastructure. A number of other countries have invested much larger percentages of their GDP on infrastructure than Brazil, such as Chile around 5\%, Peru around 4.2\%, India around 6\%, and China around $8 \%$. These countries understand the correlation between investments on infrastructure and economic development and growth (Silva, Peliano, and Chaves, 2019).

Brazil will have to invest close to $4.3 \%$ of its GDP on infrastructure if it is to become more competitive in the next two decades. This amounts to US\$ 2 trillion dollars in the next two decades. The only way to revamp Brazil's infrastructure is by bringing private companies and investors into the mix. Privatizations, concessions, and Public-Private-Partnerships are the only way to modernize and expand Brazil's Infrastructure. The goal is to increase the participation of the private sector in Brazil's infrastructure from $54 \%$ in 2019 to close to $60 \%$ by 2022. The private sector operates $100 \%$ of Brazil's telecommunication industry, $60 \%$ of the power generation industry, $7 \%$ of all state highways, $65.5 \%$ of Brazil's railroads, $57 \%$ of Brazil's airports, $72 \%$ of energy distribution, $39 \%$ of energy transmission and distribution, $14 \%$ of federal highways, $60 \%$ of ports, and only $6 \%$ of Brazil's sewage treatment industry. In terms of logistics Brazil is heavily dependent on highways to transport close to $66 \%$ of its cargo, railroads only accounting for $20 \%$, and hydroways for $12 \%$. In order to assure an increasing participation of the private sector in Brazil's infrastructure, the government needs to establish clear and transparent rules and guidelines, as well as a legal framework to protect foreign investors. Moreover, corruption schemes also need to be eliminated in order to avoid another corruption scandal such as the "Lava Jato" corruption scheme (Martins and Furlan, 2018).

Brazil is ranked in $9^{\text {th }}$ place in the world when comes to investments in IT. In Latin America Brazil's leads investments in TI (US\$ 47 billion), followed by Mexico (US\$ 22 billion), and Argentina (US\$ 8 billion). When comes to ITC, Brazil leads with investments of US\$ 97 billion, Mexico with US\$ 52 billion, and Argentina with US\$ 19 billion Still, the expansion and diffusion of internet services is a challenge for Brazil. For instance, only $38.5 \%$ of all Brazilian municipalities have access to wide band. The goal is to expand the reach to $55 \%$ of all Brazilian municipalities by 2022 (Wiziack, 2019).

In 2020, Brazil will host the world's largest bid for fifth generation cellular network technology - 5G. Brazil will be one of the first Latin American countries to implement 5G. The Brazilian Telecomunications Agency "ANATEL" will oversee the bid, expcted to gross close to US\$ $5-6$ billion dollars. Frequencies $2.3 \mathrm{GHZ}$ and 3.5 GHZ will be allocated to 5G. Two additional frequencies, $26 \mathrm{GHZ}$ and $700 \mathrm{MHZ}$ may also be added to the auction. $5 \mathrm{G}$ is a vital pre-requirement for the implementation of the "Internet of Things - IoT" and Industry 4.0 in Brazil (Deloitte, 2019; Bakker. Leferink, and Smits, 2019; Reuters, 2019).

\section{Logistics}

Logistics also demand more attention from the current administration. Currently, $82 \%$ of all cargo transported in Brazil is done by trucks on highways. Brazil has 1.7 million kilometers of roads and highways. However, 1.35 million kilometers are not paved, only 213.4 thousand kilometers are paved. The logistics density in Brazil is also very low. For instance, in the U.S., the number of kilometers of highways in relation to the geographical area is close to 431 kilometers per 1,000 of square kilometers, in Brazil is only 24.8. This has a direct impact on the cost of logistics and cost of transportation. In the last 15 years Brazil has only invested on average $0.5 \%$ of GDP on transport and logistics, when it should have been investing at least $2.2 \%$ of Brazil's GDP (Pereira, 2019b).

There has also been a emergence of new ports allowing the agricultural production of new agricultural frontiers to reach international markets. For instance, the Terminal de Graos Ponta da Montanha (TGPM) in the city of Barcarena in the state of Para in 2018 exported 3.2 million tons of soybeans and corn. The amount exported has been growing steadily since 2009. The highway system supplying these ports are however in precarious quality. For instance, BR-163 supplies the soybean produced in the state of Mato Grosso that needs urgent attention. BR-364 is another major highway taking Mato Grosso's soybean to Porto Velho in the state of Rondonia. From there it reaches the ports of Itacoatiara in the state of Amazonas or ports in the state of Para, Santarem or Barcarena (Navarro, 2019

\section{Innovation}

In 2019, Brazil is only investing close to $1.27 \%$ of its GDP on R\&D, or US $\$ 12.5$ billion. A far cry from what other nations are investing. As a result, Brazil ranks very low in the world when comes to innovation. According 
to the 2018 Global Innovation Index, Brazil ranked $66^{\text {th }}$, reflecting past administrations lack of support for R\&D and innovation efforts in Brazil. As a result, Brazil is getting caught in the innovation divide. For instance, in 1995 Brazil accounted for $0.24 \%$ of global patents, in 2016 Brazil's share had declined to only $0.07 \%$. Bolsonaro is planning to increase expenditure on $R \& D$ and innovation from the current $1.3 \%$ to $2.5 \%$ in the next four years. Sectors such as biotechnology, nanotechnology, robotics, and automation will receive special attention (Gouvea and Kassicieh, 2012; Fraga, 2019b).

Moreover, Brazil's closed economy does not create an enticing and challenging environment for Brazil's private sector to engage in innovation and R\&D. Brazil's private sector only accounts for $47.6 \%$ of Brazil's total expenditures on R\&D. In the age of $\mathrm{AI}$ and a knowledge-driven globalization process where companies and nation's competitiveness is measured by their commitment, efforts, and successes in the R\&D and innovation dimension, Brazil's must devise strategies to not fall victim of the innovation divide (Siqueira, Souza, and Barbosa, 2019).

Manufacturing 4.0 is revolutionizing the global business environment. Brazil is lagging in the use of automation in its business environment. Brazil has a very small inventory of robots. In 2017, Brazil only had 12.3 thousand robots, compared to China's 473,000, Japan's 297,000, and the U.S.'s 262 thousand. In Latin America, Mexico has more 27,000 robots. Brazil is ranked 18th in the ranking of nations with robots, accounting for only $0.6 \%$ of all global robots used, it is a very small number of robots for the world's $9^{\text {th }}$ largest economy. Brazil has 13.6 robots for each 10,000 workers, when the average is around 80 robots for each 10,000 workers. Brazil is in $41^{\text {st }}$ place in this dimension as well. On additional barrier for the further dissemination of robots in Brazil is related to the low level of education of Brazil's labor force and the low cost of labor in Brazil (Deloitte, 2019; Vasconcelos and Villas Boas, 2019).

Recently, Brazil is seeing the emergence of a vibrant venture capital environment. For decades, the lack of venture capital and angel networks deeply affected Brazil's ability to develop a vibrant innovation ecosystem. In 2019, Brazil is finally developing a dynamic venture capital industry. For decades, venture capital and angel networks were not present in Brazil's innovation environment. However, in the last few years Brazil's innovation environment has welcome these two key players in its innovation scene. In 2018, venture capitalists invested close to US\$ 1.3 billion, a volume 51\% larger than in 2017 . This amount represented close to $65 \%$ of all venture capital investments in Latin America. In Brazil funds such as "Kaszek, Redpoint, Valor Capital, and Venture, are leading the venture capital industry in Brazil. In March of 2019, the Japanese Softbank announced a US\$ 5 billion fund to invest in startups in Latin America (Pereira, 2019a).

\section{Challenges and Opportunities}

The Bolsonaro administration is undertaking a number of measures and policies to have the private sector leading the economic transformation in Brazil's business environment. This is clearly a major departure from the last decades, when the state was the protagonist of economic leadership in the country. This state-led economic strategy clearly did not produce the expected results. In 2019, the Bolsonaro administration is dealing with a legacy of economic and social failures from past administrations (Barua, 2019; Dyniewicz, 2019; O'Grady, 2019; Silimbergo and Srinivasan, 2019).

However, a number of Bolsonaro's administration economic, social, and environmental policies and measures will have to be approved by Brazil's lower house and Congress. The high political fragmentation expressed in the existence of 30 political parties makes political negotiations and compromises extremely hard and time consuming. The approval of the "Pension Reform" was accomplished, demonstrating the government's ability to push forward a key reform necessary for Brazil's fiscal stability in the short and medium term. However, the pension reform was just one of a number of key necessary reforms in Brazil. The Tax reform and the political reform are also extremely important to help unleash Brazil's entrepreneurs' "animal spirit." (Borges, 2019a; Frias, 2018; Cohen, Stefano, and Jankaski, 2019; Neuman, 2019; Otta, 2019a)

Microeconomic reforms are being implemented, reducing the cost of doing business in Brazil. Simultaneously, a privatization program is back on track attracting investors to Brazil's infrastructure projects and to the energy sector. The increasing presence of the private sector in Brazil's infrastructure projects is a vital component in revamping Brazil's infrastructure (Alemi and Pereira, 2019; Moreira, 2019; Navarro, 2019; Rodrigues, 2019a,b).

The design of new trade agreements with the U.S., the European Union, Japan, and Mexico will create a new momentum for Brazil's economy in global markets. Increasing domestic competition will also induce higher levels of productivity and competition, and innovation. Brazil's economy has been too protectionist for too long (Otta, 2019b; PWC, 2019; Rangel, 2019; United States Department of State, 2019). 
The cut in government expenditures in 2019 also point to a more effective fiscal policy aiming at reducing the role of the state in the economy, as well as assessing excessive and abusive use of government resources by the its different entities and agencies. New hires have been postponed, aiming at reducing government fiscal deficits (O’Grady, 2019; PWC, 2019).

Still, the Bolsonaro administration needs to "jump start" the economy. In 2019, Brazil's economy is only expected to expand by $0.9 \%$, short of an impact on job creation. Brazil's $11.8 \%$ unemployment rate generates a number of social and political pressures that needs to be addressed in the short and medium term. In 2019, Brazil is facing 12.5 million people unemployed, of which close to $56 \%$ are professionals with average and above average education and skills. In the manufacturing sector, close to $25 \%$ of the installed capacity is idle, allowing factories to expand production without needing to invest in new machinery and equipment. Moreover, 210,000 companies in Brazil's service industry have shut down their operations. Brazil's recession has lasted longer than projected. The "Lava Jato" corruption initiative also affected a number of Brazil's largest construction companies that in the past were largely responsible for employing Brazilians with low skill levels. Thus, creating additional barriers for a quick boost on the employment of professionals from the bottom of the pyramid (Azevedo, 2019; Dyniewicz, 2019; Neuman, 2019; Van Erven, 2018Werneck, 2019).

Brazil's government debt is around 77\% of GDP, what does not give the government the degrees of freedom to start a new economic recovery. This recovery has to come via the private sector, foreign direct investment and domestic consumption. In the second half of 2019, the government is trying to put in place measures to increase domestic consumption as another avenue to boost Brazil's GDP. Access by 100 million workers to their share in the FGTS and PIS/PASEP funds are bound to increase Brazil's domestic consumption in the short term. Still, Brazil needs to attract foreign direct investment in order to create another economic momentum. Lower levels of global economic growth will however create some obstacles for Brazil's ability to attract more FDI.

(Martins, 2019; Moreira, 2019).

\section{Final Remarks}

In 2019, Brazil is going through an economic inflection point. The Bolsonaro's administration is chartering a new economic and business paradigm for the country. The past economic paradigm lead to economic stagnation, high unemployment, a highly protectionist economy, and low levels of competitiveness. Several of the measures being implemented aim at unlocking Brazil's economic potential, by increasing Brazil's economy competitiveness and efficiency. Measures such as privatization redesigns the role of the state in Brazil's economy increasing the overall efficiency and competitiveness of Brazil's economy and business environment. Moreover, it is a transformation from a state-led growth strategy to a private sector- led economic growth strategy.

Measures to curb corruption schemes, such as the Lava-Jato, will allow Brazil to achieve higher levels of effective governance and strengthens Brazil's institutions, a pre-condition for Brazil to transition to higher levels of economic development. Brazil's pervasive corruption deeply affected the country's social, economic, and political fabric.

Opening up Brazil's economy to foreign competition is also an important step in creating more competition in Brazil's domestic market, a fundamental step in promoting innovation and market efficiency. Trade only accounts for $24.6 \%$ of Brazil's GDP, a very small percentage in relation to other emerging economies around the globe. At the global level, Brazil only accounts for $1.5 \%$ of global trade, showcasing the low competitiveness of Brazilian products and the low penetration of Brazil in global supply chains. The push for Brazil to develop more bilateral trade agreements will result in higher levels of trade and insertion of Brazilian companies in global markets.

The Bolsonaro administration has a challenging task ahead. The first steps to address Brazil's more pressing economic, social, and environmental issues are gradually being set in place. Brazil's strong foreign reserves, low levels of inflation, low levels of interest rates, a healthy flow of foreign direct investment, and abundant energy supply will facilitate this transaction. Brazil's sluggish productivity, low levels of economic competitiveness, high government debt, and high unemployment also call for immediate attention. Moreover, Brazil's acute income inequality also needs to be addressed in a proactive fashion. The Bolsonaro administration will have to also stress the establishment of a more inclusive and equitable society and economy for all Brazilians.

The microeconomic and macroeconomic reforms being implemented are crucial steps in bringing Brazil to its full economic potential. Still, Brazilian policymakers will have to address the innovation and environmental challenges permeating Brazil's economy. The knowledge and environment driven globalization process also imposes a number of challenges for Brazil's path towards a sustainable and knowledge driven economic growth 
and economic development strategy.

Higher rates of global economic development and trade will also have a definite impact on Brazil's ability to grow at faster rates. Brazil's push to develop bilateral trade agreements with the U.S. and the E.U have the potential to bring a new momentum to Brazil's economy. Moreover, foreign direct investment is a key element in Brazil's strategy to achieve higher rates of economic growth and development.

\section{References}

Adeodato, S. (2019). Eolicas Avancam com Novos canais de Comercializacao. Valor, 31 de Julho, F.6.

Agostini, R (2019). Exportador Lucra com Guerra EUA-China. O Estado de Sao Paulo, 5 de Maio, B.6.

Alemi, F., \& Pereira, R. (2019). Bico 2.0 e Alternativa para 400 mil Brasileiros. O Estado de Sao Paulo, 4 de Agosto, B.4.

Amorim, O. (2018). La Crisis Politica sin Fin y las Elecciones de 2018 en Brasil. Fundacao Getulio Vargas/EBAPE. Rio de Janeiro: Fundacao Getulio Vargas.

Araujo, C., \& Ribeiro, M. (2019). Economia com Servico Digitalizado pode ir a R\$ 6 bi. Valor, 22 de Maio, A.2.

Azevedo, R. (2019). Lava Jato Torra a Riqueza e os Empregos: Odebretcht em Recuperacao Judicial. Folha de Sao Paulo, 17 de Junho, A.16.

Bakker, E., Leferink, B., \& Smits, P. (2019). 5 G in Brazil - the State of Affairs. Netherlands Enteprise Agency.

Banco Central do Brasil. (2019). Relatorio de Investimento Directo. Brasilia: Banco Central do Brasil.

Barbosa, R. (2019). Acordo de Livre-Comercio Brasil-EUA. O Estado de Sao Paulo, 13 de Agosto, A.2.

Barua, A. (2019). Brazil: Economy Labors Through Contraction. New York: Deloitte.

BNDES. (2019). 2019-2022 Investment Outlook. Rio de Janeiro: BNDES.

Borges, A. (2019a). Governo Fecha Acordo Pro-Agenda Ambiental. O Estado de Sao Paulo, 13 de Agosto, A.6.

Borges, A. (2019b). Area mais Carente da Infraestrutura, Saneamento so Cobrira Pais apos 2060. O Estado de Sao Paulo, 1 de Abril, B.1.

Cafardo, P. (2019). Muito Espinafre e Pouco Sorvete. Valor, 16 de Julho, A.2.

Calheiros, R. (2019). Da para Ver 3 Bolsonaros, e com um deles e Possivel Dialogar, dis Renan. Folha de Sao Paulo, 11 de Outubro, A.12.

Carranca, T. (2019). Turbulencia Externa pode Tirar 0.2 ponto do PIB este Ano. Valor, 16 de Agosto, A.4.

Chiara, M. (2019). Informalidade e Beneficios Respondem por $40 \%$ daRenda das Familias do Pais. O Estado de Sao Paulo, 24 de Marco, B.1.

Chiaretti, D., \& Vasconcelos, G. (2019). Corte de Verba Norueguesa Ameaca Fundo Amazonia. Valor, 16 de Agosto, A.6.

Cohen, D., Stefano, F., \& Jankavski, A. (2019). Por que esta Tao Devagar? Exame, Edicao 1195, Ano 53, No.19, 21-33.

Collor, F. (2015). Reconstrucao Politica Brasileira: Base e Components para a Reforma Politica. Senado Federal. Brasilia: Senado Federal.

Dalpiva, J., \& Setti, R. (2019). Presidente diz que, nos EUA, Filho Buscara Mineradores. O Globo, 28 de Julho, 10.

Deloitte. (2019). Insights about Digital Transformation and ICT Opportunities for Brazil (2nd ed.). New York: Deloitte.

DiCunto, R., Lima, V., \& Ribeiro, M. (2019). Com 379 Votos, Camara AProva Previdencia. Valor, 11 de Julho, A.12.

Dyniewicz, L. (2019). Cinco Anos Apos of Inicio da Recessao, nehum setor Voltou ao Nivel Pre-Crise. O Estado de Sao Paulo, 20 de Maio, B.1.

Eichengreen, B. (2019). Desaceleracao Foi Agravada de Forma Desnecessaria. O Estado de Sao Paulo, 11 de Agosto, B.4.

Endo, M. (2019). Infrastructure and Privatization Market is Heating Up. Sao Paulo: KPMG.

Estado de Sao Paulo. (2019a). O Estado Empresario. Estado de Sao Paulo, 7 de Outubro, A.3. 
Estado de Sao Paulo. (2019b). O Brasil e a Industria 4.0. O Estado de Sao Paulo, 19 de Outubro, A.3.

Favaro, C. (2019). Producao de Petroleo em Terra Cai 50\%. O Estado de Sao Paulo, 4 de Agosto, B.12.

Filho, R. (2019). Cenario do Saneamento no Brasil: Desafios e Perspectivas. Instituto Trata Brasil. Sao Paulo: Instituto Trata Brasil.

Fraga, A. (2019a). Reforma Tributaria Sera mais Dificil que a da Previdencia. O Estado de Sao Paulo, 25 de Julho, B.6.

Fraga, E. (2019b). Entra e Sai em Instituicoes como BNDES e Embrapa freiam inovacao, diz MIT. Folha de Sao Paulo, 20 de Julho, A.20.

Frias, M. (2018). Economia na Sombra. Folha de Sao Paulo, 12 de Outubro, A.17.

Fucs, J. (2019). Venda de Estatais pode Atingir Recorde no Pais. O Estado de Sao Paulo, 14 de Julho, B.4.

Gendreau, B., \& McLendon, T. (2019). 2019 Latin American Business Environment. Center for Latin American Studies. Gainesville, FL: University of Florida.

Goitia, V. (2019). Brasileiro leva 1 hora para producir o que Americano faz em 15 minutos. UOL, economía, 19 de Marco, 16.

Goncalves, R. (2018). Governo Bolsonaro, Brasil 2019-22: Cenarios. Texto para Discussao 016/2018. Instituto de Economia. Rio de Janeiro: Universidade Federal do Rio de Janeiro.

Gouvea, R. (1998). Floods of Fortune: Sustainable Business Strategies in the Brazilian Amazon Region. Latin American Business Review, 1(2), 97-117. https://doi.org/10.1300/J140v01n02_06

Gouvea, R., \& Kassicieh, S. (2012). Bridiging the Innovation Divide: The Brazilian Experience. Thunderbird International Business Review, 54(3), 275-289. https://doi.org/10.1002/tie.21461

Gouvea, R., \& Montoya, M. (2014). Building an Equitable Green Economy: A Brazilian Perspective. International Journal of Environmental Studies, 71(2), 182-199. https://doi.org/10.1080/00207233.2014.898372

Gouvea, R., Kapelianis, D., \& Lee, S. (2019). Fostering intra-BRICS trade and investment: The Increasing Role of China in the Brazilian and South African Economies. Thunderbird International Business Review (Forthcoming). https://doi.org/10.1002/tie.22098

Gouvea, R., Kapelianis, D., \& Montoya, M. (2018). Marketing Challenges and Opportunities in Emerging Economies: A Brazilian Perspective. Thunderbird International Review, 60(2),193-205. https://doi.org/10.1002/tie.21840

Grieger, G. (2019). The Trade Pillar of the EU-Mercosur Association Agreement. Brussels: European Parliament.

Guimaraes, A. (2019). Unir Producao e Preservacao Ambiental e o Unico Caminho. O Estado de Sao Paulo, 7 de Agosto, A.4.

Gutierrez, M. (2019). Reforma da Previdencia. Rio de Janeiro: COPPEAD/UFRJ.

Hartung, P. (2019). Ainda Lidamos com o Lixo como na Idade Media. O Estado de Sao Paulo, 6 de Agosto, A.2.

Heritage Foundation. (2019). Index of Economic Freedom. Washington, D.C.: The Heritage Foundation.

Holland, M. (2019). Fiscal Crisis in Brazil: Causas e Remedios. Brazilian Journal of Political Economy, 39(1), 1-14. https://doi.org/10.1590/0101-35172019-2918

IMF. (2019). World Economic Outlook. Washington, D.C.: IMF.

ITU. (2019). ICT Development Index. San Jose, CA: ITU.

Jetro. (2018). Jetro Global Trade and Investment Report. Tokyo, Japan: JETRO.

Lamucci, S. (2019). Brasil Perde Terreno na Corrida do PIB per capita. Valor, 21 de Maio, A.4.

Lavado, T. (2018). Em Baixa Velocidade. Exame, Edicao 1167, 52(15), 61-64.

Leal, S., \& Gouvea, R (2018). The U.S.-Brazil Relationship Opportunity: Business Synergies for an Uncertain Global Environment. Thunderbird International Business Review, 60(4), 497-510. https://doi.org/10.1002/tie.21961

Lindner, J. et al. (2019). Agronegocio Pressiona Contra Retorica Ambiental. O Estado de Sao Paulo, 7 de Agosto, A. 4 
Luque, C., Silber, S., \& Zagha, R. (2019). Ensinamentos da Revolucao Agricola Brasileira. Valor, 11 de Julho, A.18.

Maia, C. (2019). BP Avanca em Geracao Solar no Brasil. Valor, 5 de Julho, B.2.

Mano, A. (2019). Brazil, Mexico begin trade talks amid Bolsonaro push for export deals. September 9th. New York: Bilaterals.

Martins, R., \& Furlan, F. (2018). A Raiz do nosso Atraso. Exame, Edicao 1167, 52(15), 20-28.

Matsumura, E. et al. (2019). Consideracoess sobre a Produtividade da Economia Brasileira. Documento de Apoio ao PNE 2050. EPE. Brasilia: Ministerio de Minas e Energia.

MDIC. (2019). Departamento de Estatistica e Apoio a Exportacao. Brasilia; MDIC.

Mendonca, A. (2019). 600 mil casos de Dengue. O Estado de Sao Paulo, 22 de Julho, B.9.

Menezes F., Naercio., C., \& Komatsu, B. (2014). A Evolucao da Produtividade no Brasil. Policy Paper No.12, Agosto. Sao Paulo: Insper Instituto de Ensino e Pesquisa.

Ming, C. (2019). Depois do Passo a Frente, Quais os seguintes? O Estado de Sao Paulo, 12 de Julho, B.2.

Ministerio da Agricultura. (2019). Agropecuaria em Numeros. Brasilia: Ministerio da Agricultura.

Ministerio da Economia. (2019). Brazil: Macroeconomic Monitor and Reform Agenda. August 6. Brasilia: Ministerio da Economia.

Ministerio de Minas e Energia. (2019). Resenha Energetica Brasileira. Secretaria de Planejamento e Desenvolvimento Energetico. Brasilia: Ministerio de Minas e Energia.

Ministry of Economy. (2019). The New Gas Market in Brazil. CWC World Gas Series - Brasil \& The Americas Summit. May 21. Brasilia: Ministry of Economy.

Mondin, M. (2019). Solucoes Biologicas e o Futuro da Tecnologia na Agricultura. Valor, 21 de Marco, A.12.

Morais, J. (2019). A Agenda 2030 das Nacoes Unidas. Valor, 20 de Julho, A.13

Moreira, T. (2019). O Papel do Consumo na Recuperacao. Valor, 4 de Julho, A.17.

Navarro, K. (2019). Gargalos ainda Limitam Escoamento no Norte. Valor, 15 de Julho. B.10.

Neuman, D. (2019). Por Que nao Crescemos. Valor EU \& Final de Semana, 12 de Julho, 4-9.

O'Grady, M. (2019). Brazil's Market Revolution. Wall Street Journal, September 29th, 19.

OECD. (2015). PISA-for-Schools. Paris, France: OECD.

OECD/ECLAC. (2019). Latin American Economic Outlook. Paris, France: OECD.

Ortega, P. (2019). PF Poe Operacao Ojuara contra Desmatamentos, Lavagem de Dinheiro e Corrupcao na Floresta. $O$ Estado de Sao Paulo, 8 de Maio, 18.

Otta, L. (2019a). Previsao de R $\$ 2$ bi do BNDES para Projeto de Infraestrutura e Insuficiente. Valor, 31 de Julho, A.2.

Otta, L.(2019b). Calendario Eleitoral Eleva Nivel de Incerteza em Acordo com os EUA. Valor, 3 de Agosto, A.2.

Otta, L., Nunes, F., \& Batista, R. (2019). Exportador Teme Acoes de Novo Governo. Valor, 17 de Outubro, B.4.

Pastore, A. (2019). Por Uma Verdadeira Reforma Tributaria. O Estado de Sao Paulo, 21 de Julho, B.3.

Patu, G. (2019). Gasto com Servidores vai a R\$ 928 bi e Atinge Maior Patamar da Historia. Folha de Sao Paulo, 21 de Julho, A.15.

Pereira, R. (2019a). Muito DInheiro e Pouco Medo de Errar. O Estado de Sao Paulo, 12 de Maio, B.3.

Pereira, R. (2019b). Por Que o Governo Teme Tanto os Caminhoneiros. O Estado de Sao Paulo, 22 de Maio, B.5.

Pupo, F. (2019). Investimento da Uniao no ANo e o Menor da Serie Historica. Valor, 17 de Maio, A.5.

PWC. (2019). Doing Business and Investing in Brazil. Sao Paulo: PWC.

Rangel, G. (2019). Brazil: The Bumpy Road to Reform. Sao Paulo: ING.

Reuters (2019). Para Nokia, Leilao de 5G do Pais deve ser o Maior do Mundo. Estado de Sao Paulo, 7 de Agosto, B.12. 
Rittner, D. (2019). EUA e UE Disputam Mercado de US\$ 50 bi por Ano no Brasil. Valor, 13 de Agosto, A.11.

Rodrigues, L. (2019a). MP da Liberdade Economica Avanca. O Estado de Sao Paulo, 12 de Julho, B.5.

Rodrigues, L. (2019b). Setores Temem uma Abertura Velada. O Estado de Sao Paulo, 27 de Julho, B.3.

Rodrigues, L., \& Agostini, R. (2019). Mercosul-UE nao pode Prejudicar EUA, diz Secretario. O Estado de Sao Paulo, 31 de Julho, B.4.

Romero, J. (2019). O que Esperar do Acordo Comercial Mercosul - UE. Valor, 3 de Agosto, A.12.

Santos, E. (2019). Brazil Economic Outlook. Third Quarter 2019. July 22nd. Bilbao, Spain: BBVA.

Secretaria de Politica Economica. (2019). Nota Informativa, Muito Alem da Previdencia: A Economia nos Primeiros Nove Meses de Governo. Brasilia: Ministerio da Economia.

Silimbergo, A., \& Srinivasan, K. (2019). Brazil: Boom, Bust, and the Road to Recovery. Washington, D.C.: IMF.

Silva, E., Peliano, A., \& Chaves, J. (2019). Construir Infraestrutura Resilientes, Promover a Industrializacao Inclusiva e Sustentavel, e Fomentar a Inovacao: O que Mostra o Retrato do Brasil? ODS 9. Brasilia: IPEA.

Siqueira, E., Souza, C., \& Barbosa, A. (2019). Using a Digital Divide Index Among Enterprises in the Context of Public Policies in Brazil. The Electronic Journal of Information Systems in Developingt Countries, 85(3), 1-25. https://doi.org/10.1002/isd2.12088

Stephenson, M. (2019). A Lava Jato nao e so a Operacao, mas um Estado de Espirito. Interview. O Estado de Sao Paulo, 21 de Outubro, A.20.

Transparency International. (2019). Corruption Perception Index. Berlin, Germany: Transparency International.

Troyo, M. (2019). Com o Acordo Mecosul-UE, o comecio exterior fica mais Importante para o Brasil. Brasilila: Ministerio da Economia.

UN. (2019). Human Development Index. New York: United Nations. .

United States Department of State. (2019). U.S. Relations With Brazil. Washington, D.C.: State Department.

Valenti, G. (2019). Empresas Brasileiras Respondem por 30\% dos Acordos da Lei Anticorrupcao dos EUA. Valor, 25 de Maio, A.10.

Van Erven, L. (2018). A Operacao Lava-Jato e o Emprego na Economia Brasileira no Curto Prazo. Monografia de Final de Curso, Departmento de Economia. Rio de Janeiro: Pontificia Universidade Catolica.

Vargas, M., Nascimento, B., \& Rocha, A. (2019). Bolsonaro Diz que Vai Privatizar Correios, Ministro Nega. $O$ Estado de Sao Paulo, 7 de Agosto, B.3.

Vasconcelos, G., \& Villas Boas, B. (2019). Brasil Perde a Corrida da Automacao Industrial. Valor, 27 de Julho, A.3.

Vieira, R. (2018). Quando o Verde Vale Mais. Exame, Edicao 1167, Ano 52(15), 98-100.

Vieira, R. (2019). Uma Luz no Cipoal de Dados. Exame, Edicao 1180, 53(4), 58-61.

Villas Boas, B. (2018). Extrema Pobreza Avanca e e Recorde em 9 Estados. Valor, 9 de Outubro, A3.

Villas Boas, B., \& Saraiva, A. (2019). Uso de Carvao ou Lenha para Cozinhar cresce 27\% e atinge 14 milhoes de Lares. Valor, 23 de Maio, 18.

Von Doellinger, C. (2019). Uma Estrategia de Retomada da Economia. Valor, 4 de Julho, A.16.

Warth, A., \& Lindner, J. (2019). Programa deve Reduzir Preco de Gas em ate 40\%. O Estado de Sao Paulo, 24 de Julho, B.4.

Watanabe, M. (2019). Apos Queda em 2018, Investimento Chines deve Retomar Folego. Valor, 2 de Maio, A.4.

Werneck, R. (2019). As Proximas Reformas. O Estado de Sao Paulo, 12 de Julho, B.6.

WIPO (2019). Global Innovation Index. Geneve, Switzerland: WIPO.

Wiziack, J. (2019). Leilao de 5G COloca em Xeque TV por Assinatura, ete teles tentam ganhar Tempo. Folha de Sao Paulo, 4 de Agosto, 1 - Mercado.

World Bank. (2018). Logistics Performance Index. Washington, D.C.: World Bank

World Bank. (2019a). Global Monthly. Washington, D.C.: World Bank.

World Bank. (2019b). Doing Business 2020. Washington, D.C.: World Bank 
World Bank. (2019c). World Bank Data Bank. Washington, D.C.: World Bank

WTO. (2019). World Trade Statistical Review. Geneve, Switzerland: WIPO.

Yale University. (2018). Environmental Performance Index. New Haven, CT: Yale University.

\section{Copyrights}

Copyright for this article is retained by the author(s), with first publication rights granted to the journal.

This is an open-access article distributed under the terms and conditions of the Creative Commons Attribution license (http://creativecommons.org/licenses/by/4.0/). 